\title{
Court-appointed scientists provide technical expertise
}

Washington. Judges at all levels of the US legal system have begun using court-appointed researchers to help them resolve contentious technical issues. Such impartial third-party experts serve as a counterweight to 'expert witnesses' hired by either plaintiffs or defendants by offering impartial advice to clarify issues for judges and juries.

A recent case demonstrates the power of a court-appointed expert. In 1989, Computer Associates International Inc. (CAI) claimed that Altai Inc. had copied a CAI computer program, thereby violating soft-

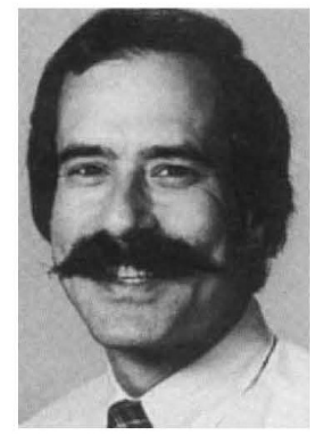

Dr Randall Davis ware copyright laws. To untangle the technical details, US Circuit Court Judge George Pratt of New York called in Randall Davis, associate director of the artificial intelligence laboratory at the Massachusetts Institute of Technology.

Davis studied the legal criteria used to evaluate a computer program's originality - and found that those criteria, set by a judge in 1976, were "incoherent". Pratt agreed and proposed a new standard for appraising possible copyright violations. In June, a New York appeals court upheld Pratt's decision.

Such court-appointed experts are neutral informants paid to help juries and judges understand the scientific details of product liability lawsuits, patent cases and other highly technical cases. A series of asbestos lawsuits in the late 1980 s illustrates what court-appointed experts do and their considerable credibility.

Confused by conflicting testimony, a judge for the US district court in Cincinnati asked neutral pulmonologists to testify about whether the plaintiffs suffered from asbestos-related disease. Although juries tend to side more with the plaintiffs in such cases, the juries in these cases followed the opinion of the court experts in 13 of the 16 cases and awarded money to only four plaintiffs.

The appearance of such court experts is still the exception rather than the rule. A study by the Federal Judicial Center (FJC), a government research institute serving the judiciary, found that only 20 per cent of federal district court judges have ever relied on a court-appointed expert. Moreover, half of those judges had appointed an expert only once.

The most frequently appointed experts were medical professionals, followed by computer engineers and program designers. Fewer than 10 per cent were natural scientists, according to the FJC study.

Although few judges rely on courtappointed experts, many have occasionally wished for help in sorting out conflicting testimony. Judges are particularly baffled by cases involving DNA testing, by toxic torts-suits claiming that a substance causes cancer or other health problems-and by lawsuits over biotechnology and computer patents. When the plaintiff's experts and the defence's experts completely contradict each other on arcane technical issues, judges and juries do not know whom to believe.

Court-appointed experts perform a variety of duties to help break down such legal logjams. Sometimes court experts act only as advisers, defining the terms and basic principles of statistics or neurology. In other cases, they comment on the evidence presented by the two sides.

Few judges allow their court-appointed experts to tackle issues as fundamental as those examined by Davis. Part of the reason is their belief that court-appointed experts strike a blow at the adversarial system, one of the foundations of US jurisprudence. A 'neutral' third witness, they fear, might disrupt the plaintiff-versus-defence scheme for organizing trials and make it possible for juries to disregard the evidence presented. Court-appointed witnesses also make it harder for each side to control what evidence is offered.

But some judges have another, more practical, reason for being wary of courtappointed experts: science does not always provide answers that the courts can use. If a judge wants to know whether a chemical causes cancer, a call for more research will not suffice.

"I don't have a theoretical decision" to make, says Judge Carl Rubin, who presided over the asbestos suits. "I have a lawsuit. Is it more than a 50 per cent chance that $\mathrm{A}$ causes B or not? That's all we can ask."

In addition, some cases simply cannot be boiled down to scientific questions. "If people living next to a toxic dump site are claiming all kinds of injuries, to a scientist it looks like a scientific issue," says Margaret Berger, a professor of law and science at Brooklyn Law School. "To a judge it looks much more like a social problem."

Nonetheless, many scientists and judges agree that a wise use of court-appointed experts can contribute to solving difficult cases. And as cases resting upon high-technology grow in number and complexity, it is likely that more judges will rely on courtappointed experts.

Traci Watson
CHINA BRIEFS

Beljing. China will soon begin a nationwide survey of its wetlands in the wake of its acceptance of an international convention to preserve these important habitats. China's wetlands, the largest in Asia, are being eyed hungrily by developers, and its decision to become the 67th country to ratify the global convention is seen as a way of marshalling outside support for its conservation efforts. The survey by the forestry ministry, which is responsible for about 90 per cent of the country's wetlands, is expected to provide a forum for cooperation between several groups interested in preserving biodiversity that are not now working together. But there are no provisions in the survey for new research projects.

Beijing. China signalled its willingness to abide by international rules protecting intellectual property last month by joining the Universal Copyright Convention. China has had a poor record of respecting the ownership of intellectual property, and pirated versions of foreign-language books and products are commonly sold in shops marked with signs saying "no admission to foreigners". Its endorsement of the global convention means that from October it will pay for foreign copyrights with foreign currency. China's National Copyright Administration is drafting regulations to carry out the convention, and the agency that handles international traffic has expanded its services to include Britain, the United States and countries of the former Soviet Union.

Beijing. A record number of archaeologists from around the world have applied to China's State Administrative Bureau of Cultural Relics this year for permission to study Chinese artefacts. This surge of interest follows recent reports of the discoveries of human crania found in Middle Pleistocene terrace deposits of the Han River and a decorated antler fragment from a 13,000-year-old Upper Palaeolithic occupation layer in Hubei Province (Nature 357, 404 \& 356, 116; 1992). This spring, a French team was granted permission to work in the Xinjiang Uyger Autonomous Region in northwestern China and a Canadian team was allowed to work in Heilongilang Province in northeastern China. The cooperative projects are mostly those on which Chinese scientists have already done research, according to Wang Li-Mei, an official with the cultural relics bureau, and the excavations have focused on such ancient sites as the Xinjiang desert. The projects provide China with foreign funds and give its researchers access to advanced techniques. One project is a $\$ 4$ million relics protection and restoration centre in Xian, in Shaanki Province, to be funded by the Italian government. The region is surrounded by such well-known archaeological sites as the terracotta tombs and the grand tomb of China's first emperor. 